DOI https://doi.org/10.30525/978-9934-26-184-8-3

\title{
РОЛЬ МУЛЬЧУВАННЯ У ЗБЕРЕЖЕННІ ОПТИМАЛЬНИХ ФІЗИЧНИХ ПАРАМЕТРІВ ПОСІВНОГО ШАРУ ГРУНТУ
}

\author{
Крилач С. I. \\ кандидат сільськогосподарських наук, \\ стариий науковий співробітник лабораторії геоекофізики \\ трунтів імені академіка НААН В. В. Медведєва \\ Національний науковий центр «Інститут трунтознавства \\ та агрохімії імені О. Н. Соколовського» \\ м. Харків, Україна
}

В умовах сьогодення надзвичайно гостро стоїть питання збереження вологи у грунтах, а за умов зміни клімату воно набирає особливу актуальність. Дефіцит вологи часто стає однією iз основних причин, що негативно впливають на розвиток, а в подальшому і урожайність сільськогосподарських культур. Тому головним завданням землекористування $є$ впровадження ефективних прийомів накопичення та раціонального використання вологи у грунті. Для поліпшення вологозабезпеченості рослин в Україні використовується чимало технологічних прийомів i технічних засобів. Одними 3 яких $є$ новітні технології- консервативна, мінімальна й нульова в основі яких лежить зменшення випаровувальної поверхні за рахунок використання мульчування поверхні грунту.

Мульчуючи поверхню грунту різного роду матеріалами ми маємо змогу впливати на весь комплекс факторів, що визначає фізичні властивості у грунті. Найбільший вплив мульчі відмічається на вологість, особливо орного шару грунту. Вона сприяє зменшенню на 80 \% випаровування вологи та консервації вологи у вигляді роси (атмосферна іригація) у разі зіткнення атмосферного повітря 3 більш холодною поверхнею грунту [1]. У результаті досліджень Т.С. Линдіна та О.А. Сендецька [2] встановили, що мульчування поверхні грунту соломою 
призводить до збільшення запасів продуктивної вологи у орному шарі грунту на 9,5 - 11,5 мм.

Також, мульча виявилася ефективною у розущільненні грунту, саме мульча була здатною усунути зниження врожаю, що спостерігалося на фоні мінімального обробітку на опідзоленому чорноземі [3]. Дослідженнями Т.В. Соромотіної та О.Н. Федуриної [4] установлено численні позитивні зміни у грунті за застосування різного роду мульч-матеріалів. Так, застосування торфу, прозорої поліетиленової плівки та білого покривного матеріалу призводило до зниження щільності будови грунту до оптимального рівня, за даними авторів, для томатів у межах від

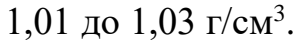

Постійне використання мульчі не тільки сприяє поліпшенню фізичних властивостей грунту, сповільненню мінералізації органічних речовин, але і припиняє водну та вітрову ерозію, i за умови безперервного застосування пригнічує розвиток бур'янів [5].

Отже, мульчування поверхні грунту має вагомий вплив на агрофізичні параметри грунту, що в свою чергу відображається на розвитку сільськогосподарських культур та їх продуктивності.

Дослідження впливу мульчування на агрофізичні властивості грунту нами було визначено у посівах двох сільськогосподарських культур це кукурудза та яра пшениця. У досліді для кожної культури було створено модельні ділянки зі штучно створеними оптимальними агрофізичними параметрами грунту 3 покриттям поверхні мульчею та без неї. Оптимальні параметри агрофізичних властивостей грунту: щільність будови в піднасіннєвому прошарку $1,0-1,2$ г/ $\mathrm{cm}^{3}$., а розмір структурних агрегатів коливався в межах від 1 до 10 мм.

Результати проведених досліджень підтверджують, що мульчування грунту перед сівбою сприяє покращенню проростання та подальшого розвитку сільськогосподарських культур. В основному, це пов'язано із зменшенням випаровування, що призводило до підвищення вмісту вологи в грунті. Під впливом мульчування накопичення вологи ми відмічали у посівах кукурудзи - запаси вологи у шарі грунту 0 - 10 см збільшилися на $3 \%$, а у 10 - 30 см - на $2 \%$, порівняно із посівами без мульчі. 
Встановлено, що мульчування разом із оптимізацією агрофізичних параметрів посівного шару грунту є ефективним засобом накопичення у грунті вологи протягом усієї вегетації сільськогосподарських культур. Вищесказане свідчить про те що, навіть невелика доза мульчі здатна зменшувати випаровування та сприяти підвищенню урожайності сільськогосподарських культур.

У ході досліджень відмічається тенденція до підвищення урожаю сільськогосподарських культур за оптимізації агрофізичних властивостей та мульчування поверхні грунту безпосередньо перед сівбою, порівняно із оптимальним посівним шаром без мульчі. Так підвищення урожаю на варіантах 3 мульчею відмічається для кукурудзи на $11 \%$, а для ярової пшениці на 15 \%. На нашу думку, це пов'язано із збільшенням вологості посівного шару грунту на початку вегетації, що сприяло інтенсивному проростанню та подальшому розвитку рослин.

Отже, у результаті аналізу літературних джерел та проведення власних досліджень доведено, що мульчування поверхні грунту позитивно впливає на параметри агрофізичних властивостей, а особливо це стосується вологості.

\section{Лiтература:}

1. Писаренко В.М., Писаренко П.В., Писаренко В.В. Напрями адаптування землеробства до змін клімату // Збірник тез II Міжнародної науково-практичної конференції «Кліматичні зміни та сільське господарство. Виклики для аграрної науки та освіти». C. 9-22.

2. Лындина Т.Е., Сендецкая О.А. К вопросу о роли мульчирования в повышении урожая зерновых культур в экстремальных условиях увлажнения // Вісник ХДАУ. 1999. № 1. С. 56-60.

3. Glab T., Kulig B. Effect of mulch and tillage system on soil porosity under wheat (Triticum destivum) // Soil and Tillage Research. 2008. № 99. P. 169-178.

4. Соромотина Т.В. Федурина О.Н. Влияние мульчирующих материалов на агрофизические свойства почвы // Аграрный вестник Урала. 2012. № 12. С. 4-6. 
5. Mulch effects on soil moisture and nitrogen, weed grow than irrigated maize productivity in a warm-temperate climate of South Africa / F.S. Murungu, C. Childuza, P. Muchaonyerwa [et al] // Soil and Tillage Research. 2011. Vol. 112. P. 58-65.

DOI https://doi.org/10.30525/978-9934-26-184-8-4

\title{
НОВІ ВИСОКОПРОДУКТИВНІ ЛІНІЇ СӦ̈ З ПОКРАЩЕНИМ БІОХІМІЧНИМ СКЛАДОМ НАСІННЯ
}

\author{
Лаврова Г. Д.
}

кандидат біологічних наук, старший науковий співробітник, завідувач відділу селекції, генетики та насінництва бобових культур

Селекційно-генетичний інститут - Наиіональний центтр насіннєзнавства та сортовивчення

Мурсакаєв Е. Ш.

молодиий науковий співробітник відділу селекиії,

генетики та насінництва бобових культур

Селекційно-генетичний інститут - Національний центр насіннезнавства та сортовивчення

\section{Коблай С. В.}

кандидат сільськогосподарських наук, провідний науковий співробітник відділу селекиії, генетики та насінництва бобових культур

Селекційно-генетичний інститут - Наиіональний центр насіннєзнавства та сортовивчення

м. Одеса, Украӥна

Соя $є$ одною 3 найбільш поширених культур світового землеробства, яка за посівними площами та валовим збором займає четверте місце серед сільськогосподарських рослин після 